\title{
Upaya Perlindungan Hukum Terhadap Industri Usaha Mikro Kecil dan Menengah (UMKM) di Indonesia
}

\author{
Nabilah Apriani ${ }^{1}$, Ridwan Wijayanto Said ${ }^{2}$ \\ ${ }^{1}$ Program Studi Ilmu Hukum, Fakultas Hukum, Universitas Pasundan, \\ Jl. Lengkong Besar No.68, Bandung, 40261 \\ ${ }^{2}$ Dinas Perindustrian dan Perdagangan Provinsi Jawa Barat, \\ Jl. Asia Afrika No.146, Bandung, 40261
}

Penulis untuk Korespondensi/E-mail: aprianinabilah@gmail.com

\begin{abstract}
MSMEs have a central role in the national economy, but the government contributes more and pays full attention to big businesses. So, this causes the need for legal protection for MSMEs. This study focuses on the discussion of how the legal protection efforts against the Micro, Small, and Medium Enterprises (UMKM) industry in Indonesia and how the concept of protecting MSMEs is based on an economic justice approach. The research method used in this study is a normative empirical legal research method, with descriptive-analytical research specifications for further data collection using literature studies sourced from primary, secondary, and tertiary legal materials for further qualitative analysis. The results of this study indicate that MSMEs as a small-scale industry still think that intellectual property protection is not important. So that it can be concluded that brand protection for MSME business actors is not only state protection against registered trademark owners but also a form of protection for the community as consumers so that the law must function to change and take sides (affirmative action) to small businesses so that they are more empowered and still exist in carrying out their duties. business together with big business.
\end{abstract}

Keywords: Effort; Legal protection; MSMEs; Indonesia

\begin{abstract}
Abstrak
UMKM memiliki peran sentral dalam perekonomian nasional, namun pemerintah lebih banyak memberi kontribusi dan perhatian penuh kepada usaha besar. Sehingga hal tersebut menyebabkan di butuhkannya perlindungan Hukum terhadap UMKM. Penelitian ini berfokus pada pembahasan mengenai Bagaimana upaya perlindungan hukum Terhadap Industri Usaha Mikro Kecil dan Menengah (UMKM) di Indonesia serta Bagaimana konsep perlindungan UMKM berdasarkan pendekatan keadilan ekonomi. Metode penelitian yang digunakan dalam penelitian ini adalah metode penelitian hukum normatif empiris, dengan spesifikasi penelitian deskriptif analitis untuk selanjutnya dilakukan pengumpulan data dengan cara studi pustaka yang bersumber pada bahan hukum primer, sekunder dan tersier untuk selanjutnya di analisis secara kualitatatif. Hasil Penelitian ini menunjukan bahwa UMKM sebagai suatu industri berskala kecil masih menganggap bahwa perlindungan kekayaan intelektual bukanlah suatu hal yang penting. Sehingga diperoleh kesimpulan bahwa Perlindungan merek terhadap pelaku usaha UMKM tidak hanya sebagai perlindungan negara terhadap pemilik merek terdaftar tetapi juga bentuk perlindungan terhadap masyarakat selaku konsumen sehingga Hukum harus difungsikan untuk mengubah dan memihak (afirmatif action) kepada usaha kecil agar lebih berdaya dan tetap eksis dalam menjalankan usahanya bersama dengan usaha besar.
\end{abstract}

Kata kunci: Upaya; Perlindungan Hukum; UMKM; Indonesia 


\section{PENDAHULUAN}

Berdasarkan konstitusi yaitu Undang Undang Dasar tahun 1945 khususnya pasal 33 ayat (1), pembangunan ekonomi nasional bertujuan untuk meningkatkan kesejahteraan seluruh rakyat Indonesia, bukan kesejahteraan perorangan maupun suatu kelompok dan golongan tertentu. Sehingga sejatinya perekonomian nasional tersebut harus berdasarkan atas usaha bersama diatas prinsip kekeluargaan demi mencapai suatu tujuan yakni kesejahteraan dan kemakmuran. Sehingga demi mewujudkan tujuan tersebut, dapat dilakukan beberapa upaya dimana salah satunya adalah dengan melakukan perlindungan hukum terhadap Usaha Mikro Kecil dan Menengah (UMKM) di Indonesia pada saat ini.

Usaha Mikro Kecil dan Menengah atau dapat disingkat sebagai UMKM merupakan industry usaha ekonomi produktif yang dikembangkan dan dikelola oleh masyarakat dengan tujuan untuk mencukupi kebutuhan hidup masyarakat (Harsono, 2014). Adapun saat ini, Undang Undang Nomor 20 Tahun 2008 telah mengatur secara spesifik terkait dengan usaha usaha apa saja yang dapat digolongkan kedalam jenis jenis UMKM.

Usaha Mikro Kecil dan Menengah atau yang disingkat sebagai UMKM umumnya adalah usaha milik perorangan atau badan Usaha keduanya sama sama disebut sebagai pelaku usaha. Pelaku usaha menghasilkan suatu produk sendiri baik berbentuk kerajinan tangan, makanan, olahan tanaman, dan lain lain. Setiap produk yang dihasilkan melalui UMKM tersebut mempunyai nilai yang terkandung baik materil maupun immaterial (Hartini, 2011). Sehingga inilah yang menyebabkan produk hasil olahan UMKM ini harus dilindungi secara hukum.

Saat ini, Industri UMKM merupakan salah satu pilar sebagai pembangkit roda perekonomian Indonesia. Hal tersebut dapat dibuktikan dengan fakta kajian kementerian perindustrian yang menyebutkan bahwa industri Usaha Mikro Kecil dan menengah (UMKM) mampu memberikan kontribusinya sebesar $60 \%$ (enam puluh persen) terhadap pembangunan ekonomi Indonesia. Hal ini menunjukan bahwa kontribusi dan peran UMKM terhadap roda perekonomian Indonesia sangatlah besar. Didukung fakta bahwa UMKM mampu menyerap sebanyak $97,22 \%$ tenaga kerja Indonesia dalam kurun waktu 5 tahun terakhir sejak tahun 2016 hingga saat ini.

Secara garis besar UMKM memiliki banyak peran lainnya dalam kegiatan ekonomi Indonesia. Selain sebagai penyumbang pendapatan terhadap neraca pembayaran, juga sebagai penyedia lapangan kerja, UMKM juga berperan besar dalam perekonomian lokal dalam pemberdayaan masyarakat serta menciptakan pasar baru (Saputra, Heniyatun, Hakim, \& Praja, 2021). Selain itu, cara mengetahui Peran UMKM terhadap perekonomian Indonesia dapat dilihat melalui melalui Produk Domestik Bruto (PDB) (Laily, 2016).

Produk Dosmetik Bruto atau yang disingkat sebagai PDB merupakan suatu nilai barang dan jasa yang diproduksi oleh negara dalam satu tahun. Tujuannya adalah untuk memberikan ringkasan terhadap aktivitas ekonomi dalam suatu nilai uang tertentu selama kurun waktu tertentu (Indayani \& Adelia, 2019). Total kontribusi yang telah diberikan UMKM terhadap PDB Nasional ini adalah akumulasi dari semua sector ekonomi UMKM. Berdasarkan data yang diperoleh dari Kementerian Koperasi dan UMKM, UMKM mampu berkontribusi sebanyak Rp. 5.440 triliun atas dasar harga berlaku terhadap PDB Nasional dalam tahun 2013.

Data tersebut membuktikan bahwa UMKM memiliki nilai stratagis untuk membantu dan memperkuat perekonomian nasional sebagai bagian dari perekonomian rakyat sehingga sudah seharusnya pemerintah memberikan atensi lebih baik dalam hal strategi maupun kebijakan bagi pemberdayaan berupa bentuk keberpihakan dan prioritas untuk UMKM yang dipandang sebagai kelompok unit usaha yang telah seharusnya terintegrasi dan tetap eksis dalam dunia industri usaha dan perdagangan yang dapat memperluas jaringan dan tarafnya. 
UMKM yang dalam hal ini sebagai cikal bakal kewirausahaan yang masih terus berproses, masih perlu untuk diberikan perhatian lebih dari berbagai aspeknya (S, 2017) Karena nyatanya mayoritas dari pelaku UMKM merupakan masyarakat dengan ekonomi menengah kebawah sehingga sangat membutuhkan perlindungan hukum (Indrawati \& Setiawan, 2020).

UMKM harus mempunyai kemampuan untuk bersaing di taraf global untuk terus mendorong terciptanya pasar yang terintegrasi sehingga dapat berkembang bukan hanya di taraf nasional tapi juga di taraf internasional. Artinya UMKM harus mempunyai peluang, dukungan, kesempatan serta perlindungan hukum dari pemerintah. Karena adanya suatu dukungan yang tegas terhadap setiap unit UMKM sama dengan memberikan keberpihakannya terhadap usaha ekonomi yang dibangun oleh rakyat.

Peluang bagi UMKM saat ini kian sempit. Hal tersebut diakibatkan karena usaha maupun kegiatan yang berpeluang untuk dilakukan UMKM justru diambil alih oleh unit usaha besar. Usaha besar ini didukung dengan manajemen usaha, jaringan pasar serta modal yang kuat yang telah berhasil menembus pasar pasar dan jaringan secara luas. Hal inilah yang menyebabkan unit usaha perintis sebagai UMKM menemukan hambatannya untuk berkembang dan menjalankan usahanya.

Meskipun berdasarkan fakta fakta diatas UMKM banyak memberikan kontribusi yang besar terhadap perekonomian rakyat, namun pemerintah lebih banyak memberikan atensinya kepada unit usaha besar. Sementara unit usaha kecil seperti UMKM dibiarkan berjalan dengan sederhana. Hal ini tentunya tidak sesuai dengan Pasal 33 UUD 1945 yang para intinya menegaskan bahwa kegiatan ekonomi harus bertujuan untuk memberikan kesejahteraan bagi seluruh rakyat Indonesia.

Selain itu, sistem pasar yang saat ini didasarkan atas mekanisme pasar juga lebih menguntungkan unit usaha besar. Sehingga akhirnya membuat unit usaha kecil seperti UMKM semakin tersisihkan dari pasar.
Akhirnya UMKM tidak memiliki kesetaraan dalam hal kesempatan untuk menjalankan usahanya sehingga pemerintah dirasa perlu memberikan perlindungan secara maksimal terhadap UMKM dan menciptakan sebuah konsep perlindungan berlandasakan keadilan ekonomi.

Berdasarkan uraian diatas, penelitian berjudul "UPAYA PERLINDUNGAN HUKUM TERHADAP INDUSTRI USAHA MIKRO KECIL DAN MENENGAH (UMKM) DI INDONESIA" ini berfokus untuk menggali secara lebih komperhensif terkait dengan kajian (1)Bagaimana upaya perlindungan hukum Terhadap Industri Usaha Mikro Kecil dan Menengah (UMKM) di Indonesia (2)Bagaimana konsep perlindungan UMKM berdasarkan pendekatan keadilan ekonomi ?

\section{METODE PENELITIAN}

Metode penelitian yang digunakan dalam penelitian ini adalah Normatif-Empiris. Metode Penelitian ini menekankan pada peraturan perundang undangan sebagai kaidah atau norma yang kemudian dilakukan analisis terhadap keadaan atau peristiwa social yang terjadi di masyarakat (Benuf, 2020).

Secara lebih lanjut penulis menggunakan spesifikasi penelitian deskriptif analitis guna menghasilkan suatu data yang kompleks dalam memecahkan permasalahan serta mengandung makna yang secara signifikan berpengaruh terhadap substansi penelitian.

Penelitian ini bersumber pada bahan hukum yang relevan dengan topik penelitian. Dalam hal ini penulis menggunakan 3 bahan hukum utama yakni bahan hukum primer yang terdiri dari aturan perundang undangan, bahan hukum sekunder yang terdiri dari buku dan hasil penelitian terdahulu, serta bahan hukum tersier berupa jurnal.

Adapun teknik yang digunakan untuk pengumpulan data dalam penelitian ini yakni dengan cara studi pustaka yaitu proses menginventarisir, mengolah dan menghasilkan konklusi berdasarkan bahan hukum atau sumber 
sumber yang diperoleh serta relevan untuk memecahkan masalah dalam penelitian ini.

Kemudian penelitian ini di analisis secara kualitatatif dengan berpedoman pada tataran yuridis sebagai hukum positif dan kemudian di analisis secara kualitatif berdasarkan bahan hukum yang telah di inventarisir untuk akhirnya dilakukan pengolahan data untuk mendapatkan suatu konklusi yang komperhensif.

\section{HASIL DAN PEMBAHASAN}

\section{Upaya Perlindungan Hukum Terhadap Industri Usaha Mikro Kecil Dan Menengah (UMKM) Di Indonesia}

Indonesia merupakan negara dengan kontribusi sebesar $60 \%$ berasal dari UMKM. Sehingga di Indonesia sendiri, UMKM merupakan unit usaha yang memberikan peranan besar dalam perekonomian nasional untuk meningkatkan devisa negara. Produk produk yang diproduksi oleh UMKM, tidak sedikit yang mempunyai nilai tinggi dan memiliki keunikannya masing masing.

Namun karena kurangnya perhatian dan perlindungan terhadap UMKM, akhirnya tidak sedikit produk UMKM Indonesia yang notabene nya bernilai tiggi dan memiliki nilai tradisionalnya justru malah dicuri oleh pihak lain. Bangsa Indonesia masih minim kesadaran terkait pentingnya perlindungan terhadap Hak Kekayaan Intelektual yang mampu memberikan nilai ekonomi yang tinggi dalam dunia usaha dan perrdagangan (Adaninggar, 2016).

Tidak dapat dipungkiri, bahwa sektor bisnis dan perdagangan erat kaitannya dengan Kekayaan Intelektual. Setiap usaha yang dilakukan pasti memiliki Kekayaan Intelektualnya masing masing (Hidayah, 2017). Kekayaan Intelektual tersebut dapat terwujud berupa Merek, Paten, Cipta, Desain Industri, Rahasia Dagang, Dasar Tata Letak Sirkuit Terpadu, serta Indikasi Geografis. Seluruhnya berbeda beda tergantung dengan hasil produksinya masing masing.

Sama halnya dengan UMKM sendiri, meskipun skala bisnis yang dijalankan oleh UMKM bukan suatu bisnis berskala besar, namun umumnya suatu UMKM harus terdapat suatu merek, baik yang disebut sebagai merek dagang maupun merek yang digunakan dalam produk jasa (Bethlehn, 2018). Sejauh ini, pelaku UMKM sering kali beranggapan bahwa kekayaan Intelektual bukanlah suatu aspek yang penting dalam menjalankan usahanya. Hal tersebut dapat didukung dengan fakta terkait masih minimnya pendaftaran Merek UMKM yang terdaftar di Ditjen Kekayaan Intelektual.

Adapun berdasarkan perolehan data statistik pendaftaran Ditjen KI menunjukkan bahwa selama periode 2016-April 2018 pendaftaran Merek Non UMKM mendominasi sebesar 91,45\% sedangkan untuk merek UMKM hanya sebesar 8,55\%,6. Padahal berdasarkan pandangan World Intellectual Property Rights (WIPO) bahwa UMKM memiliki potensi yang besar untuk terus berkembang dan menghasilkan inovasi dan kreativitas (Sardjono, Prastyo, \& Larasati, 2014).

Didalam Undang-Undang Nomor15 Tahun 2001 telah disebutkan mengenai definisi Merek. Yaitu merupakan sebuah tanda meiliputi gambar, nama, kata, hurufhuruf, angka-angka, susunan warna, atau kombinasi dari unsur-unsur tersebut yang memiliki daya pembeda dan digunakan dalam kegiatan perdagangan barang atau jasa.

Hak Merek merupakan hal yan secara ekslusif diberi oleh negara terhadap pemilik merek yang terdaftar dalam daftar umum merek dalam jangka waktu tertentu menggunakan sendiri merek tersebut atau memberi ijin kepada seseorang atau beberapa orang secara bersamasama atau badan hukum untuk menggunakannya. Tujuan dari pendaftaran ha katas merek ini adalah untuk mendapatkan suatu kepastian hukum serta perlindungan hukum terhadap hak merek.

Merek berfungsi untuk memberikan perbedaan terhadap barang dan jasa dari produk yang dihasilkan suatu perusahaan tersebut dengan perusahaan lain. Merek hadir sebagai unsur yang menjadi pembeda yang cukup (Capable of Distinguishing) dan sah dimata hukum. Artinya, 
merek digunakan sebagai daya yang berkekuatan hukum untuk membedakan hasil produksi baik benda maupun jasa antara perusahaan satu dengan perusahaan lainnya (Muhammad, 2001). Merek dapat dilakukan pendaftarannya kepada Direktorat Jenderal Hak Kekayaan Intelektual sebagai instansi yang berkapasitas melakukan pendaftaran merek yang dimohonkan oleh pemilik merek (Mamahit, 2013).

Pendaftaran merek mempunyai implikasinya tersendiri. Suatu produk yang telah mendapatkan pendaftaran atas merek akibatnya produk tersebut hanya dapat diproduksi oleh pemegang merek. Inilah yang dinamakan sebagai pemegang merek mendapatkan haknya secara ekslusif. Sehingga apabila ada pihak lain yang ingin memproduksi barang maupun jasa yang sama dengan pemilik merek lain, maka berkewajiban untuk mendapatkan sebuah lisensi dadri pemegang hak merek serta harus membayar royalti. Akibatnya, tindakan produksi yang dilakukan tanpa seijin pemegang hak merek tersebut masuk dalam kategori pelanggaran dan pembajakan yang menimbulkan suatu akibat hukum (Indrawati \& Setiawan, 2020).

Di Indonesia sendiri, perlindungan atas hak merek menganut asas konstitutif dengan prinsip firsttofile. Artinya, merek tersebut dapat memperoleh perlindungan jika merek tersebut didaftarkan terlebih dahulu kepada pemerintah melalui kementerian Hukum serta Ham dan dalam hal ini terdapat di Direktorat Kekayaan Intelektual. Sehingga jika suatu UMKM memiliki produk berupa barang maupun jasa namun tidak dilakukan pendaftaran, maka pelaku usaha UMKM tersebut akan kehilangan perlindungan hukum atas merek yang di produksinya.

Selain yang telah dijabarkan diatas, manfaat dari perlindungan Hak Kekayaan Intelektual khususnya di bidang merek terhadap UMKM diantaranya adalah berpotensi untuk meningkatkan nilai jual bagi produk UMKM serta mendapatkan hak istimewa atau yang disebut sebagai hak ekslusif atas UMKM tersebut. Sehingga melihat banyaknya keuntungan yang dapat diperoleh akibat pendaftaran merek, maka hal ini perlu untuk diupayakan terus menerus demi terciptanya suatu produk UMKM yang berkapasitas dari segi hukum dan kualitas untuk bersaing di taraf yang lebih luas lagi.

\section{Konsep Perlindungan UMKM Berdasarkan Pendekatan Keadilan Ekonomi}

Tujuan hukum adalah memberikan perlindungan bagi seluruh masyarakat. Baik masyarakat yang berada dalam posisi lemah dalam segi social, politik, maupun ekonomi, maupun masyarakat yang berada dalam posisi kuat. Hukum harus bersikap adil terhadap semua tanpa adanya pembedaan. Sehingga perlindungan hukum yang akan difokuskan dalam penelitian ini akan menyoroti pada aspek ekonomi. Terutama dalam keberadaan unit usaha kecil yang dalam hal ini merupakan UMKM dalam menghadapi persaingan usaha.

Ditinjau dari keilmuan filsafat hukum, sebuah upaya perlindungan bagi usaha kecil merupakan suatu upaya dalam merealisasikan suatu keadilan ekonomi. Hal tersebut dapat dilakukan dengan mengupayakan pemerataan dalam kesempatan berusaha. Dalam konteks ini keadilan merupakan suatu tujuan hukum yang sifatnya essensial. Pada hakikatnya hukum merupakan suatu kaidah untuk mewujudkan suatu keadilan dalam hidup bermasyarakat. Makna ini tercapai menurut Theo Huijber dengan dimasukkannya prinsip-prinsip keadilan dalam peraturan-peraturan bagi kehidupan bersama itu (Heijber, 1988).

Dalam hal ini untuk membahas suatu perlindungan ekonomi yang berkeadilan, maka akan dilakukan kajian terhadap pemikiran ahli filsafat hukum, yaitu perspektif Aristatoles, Adam Smith dan John Rawls mengenai keadilan ekonomi. Menurut Aristatoles ada 4 macam Keadilan, Antara lain: (1) Keadilan Legal, (2) Keadilan Komutatif, (3) Keadilan Distributif dan (4) Keadilan korektif (Fiedmann, 1993).

Konsep keadilan distributif Aristatoles oleh Filsuf John Rawls dijadikan sebagai dasar untuk mengkritik sistem ekonomi pasar bebas yang dipelopori oleh Adam Smith. John Rawls 
membagi keadilan berdasarkan prinsip kebebasan yang sama (equality principle), prinsip perbedaan (difference principle) dan prinsip kesempatan yang sama (principle of fair equality of opportunity). John Rawls seorang filsuf yang dalam bukunya The theory of Justice secara keras mengkritik sistem ekonomi pasar bebas. Menurut Rawls sistem ekonomi pasar bebas menimbulkan bahkan memperbesar ketimpangan ekonomi antara yang kaya "usaha besar" dengan yang miskin "usaha kecil".

Berdasarkan pendapat Rawls, pasar bebas tidaklah menjamin suatu pemerataan atas perekonomian yang adil, melainkan akan menimbulkan ketidakadilan. Karena sistem pasar bebas seperti ini menyebabkan suatu peluang untuk saling melakukan monopoli akibat adanya kompetisi terbuka.

Berdasarkan hal tersebut, Rawls menyebutkan bahwa faktor yang menyebabkan seseorang tidak mampu untuk melakukan persaingan serta melakukan usaha untuk memiliki hidup yang lebih baik adalah karena adanya ketidakadilan yang tercipta dalam masyarakat. Sehingga penyebab masyarakat kecil dan tidak berkesempatan dalam memperbaiki hidupnya, tidak selamanya karena malas bekerja namun juga karena tidak diberikan peluang untuk memperbaiki keadannya. Bagitupun akhirnya berpengaruh pada lembaga perbankkan yang berusaha untuk menutup diri akibat mereka yang tidak mampu menunjukan kolateral yang cukup (Sidarta, 2011).

Hakikatnya, kesempatan untuk berkembang menuju arah yang lebih baik inilah yang harus diakomodir oleh setiap sistem hukum yang ada. Karena menurut Rawls, sistem social yang ada harus diupayakan untuk mendukung kelompok masyarakat kecil yang kurang beruntung. Berangkat dari hal tersebut Rawls mengajukan prinsip perbedaan atau yang disebut sebagai Difference Principle.

Selain itum Rawls ingin memecahkan permasalahan terkait ketimpangan yang terjadi pada aspek ekonomi dan social akibat adanya persaingan bebas yang menurutnya memberikan dampak bagi usaha kecil. Sehingga menurutnya, solusinya adalah pengaturan harus dilakukan dalam kerangka pranata politik serta legal yang mengatur peristiwa ekonomi dan menjaga keadilan social.

Upaya penegakan ekonomi yang berkeadilan harus diselenggarakan atas dimensi kerakyatan yang memperhatikan dua prinsip utama dalam keadilan diantaranya adalah; memberikan hak serta kesempatan yang sama terhadap kebebasan dasar bagi semua orang, dan mampu untuk mengatur suatu kesenjangan baik dalam segi social maupun ekonomi sehingga dapat meghasilkan keuntungan secara timbal balik bagi semua kalangan. Baik kalangan yang beruntung maupun kurang beruntung.

Kemudian Jeremy Bentham sebagai filsuf yang beraliran utilitarian juga berpendapat bahwa hukum haruslah mempunyai prinsip melindungi yang tujuannya untuk mewujudkan suatu persamaan dalam kesempatan untuk berusaha yang diwujudkan kedalam peraturan perundang undangan untuk mewujudkan tujuan tersebut.

Dalam pandangannya, negara dapat mencegah penumpukan kekayaan oleh sedikit orang yang hidup mewah dengan mengorbankan orang banyak. Dan hal tersebut tentunya menimbulkan suatu ketidakadilan. Maka dari itu negara harus hadir dalam melindungi hak hak masyarakatnya dalam kesetaraan meskipun hal tersebut tidak tertulis dalam peraturan perundang undangan sehingga dapat tercapai fungsi hukum yang melindungi masyarakat dari berbagai kepentingan yang ada (Fiedmann, 1993).

Dalam menjalankan usaha, tujuannya adalah mencari keuntungan. Sehingga untuk mencapai hal tersebut pelaku usaha harus bersaing dengan pelaku usaha lainnya. Sehingga hal tersebut berpotensi menimbulkan ketidakharmonisan dalam persaingan. Hal ini dapat menyebabkan suatu kondisi ketidakadilan. Semua hal tersebut tidak lain adalah dampak dari persaingan bisnis yang tidak sehat. Sehingga untuk mengatasi hal tersebut, maka pemerintah dirasa perlu turun tangan untuk mengatur persaingan.

Sehingga menurut Erman Rajagukguk, suatu moral dasar dalam bisnis haruslah direalisasikan kedalam aturan tegas yang mempunyai sanksi. 
Sehingga disinilah dibutuhkan peran negara dalam mengatur suatu mekanisme persaingan bebas yakni untuk melindungi pihak yang lemah. Oleh karena itu hukum yang dituangkan juga harus mengandung nilai nilai motal. Sehingga menjadi sesuatu yang urgen pelaksanaan yang sungguh sungguh dari Undang-Undang Larangan Monopoli dan Persaingan Curang (Rajagukguk, 2000).

Khususnya di Indonesia sendiri, telah ada Aturan perundang undangan yang mengatur mengenai persaingan usaha, yakni adalah UU No. 5 Tahun 1999 tentang Larangan Praktek Monopoli dan Persaingan Usaha Tidak Sehat. UU ini diharapkan dapat berjalan sesuai tujuannya yakni untuk memberikan kesempatan yang sama bagi semua warga ikut berpartisipasi di dalam proses produksi dan distribusi barang/jasa.

\section{KESIMPULAN}

Perlindungan hukum terhadap UMKM di Indonesia dapat diwujudkan dengan melakukan pendaftaran kekayaan intelektual yakni hak merek terhadap produk yang di produksinya. Hal ini telah diatur dalam peraturan perundang undangan yang berlaku yakni Undang-Undang Nomor 15 Tahun 2001 tentang Merek. Pendaftaran atas merek bukan hanya bermanfaat bagi pelaku usaha namun juga masyarakat sebagai konsumen. Namun akibat masih terbatasnya pengetahuan UMKM terhadap merek, maka diharapkan para stakeholder terkait dapat memberikan penyuluhannya terhadap pelaku usaha UMKM.

Sistem ekonomi pasar bebas menimbulkan sebuah gap antara pengusaha besar dan pengusaha kecil khususnya UMKM. Dibutuhkan suatu konsep mekanisme perlindungan hukum yang berkeadilan untuk menjamin ketimpangan tersebut. Salah satunya adalah dengan menggunakan hukum sebagai alat yang dapat memberikan suatu perlindungan yang adil baik bagi pengusaha besar maupun pengusaha kecil. Selain itu juga, peran pemerintah sangat dibutuhkan untuk menciptakan persaingan bebas yang mendukung usaha kecil tetap eksis dalam ranah perdagangan.

\section{REFERENSI}

Adaninggar, A. W. (2016). Perlindungan Produk Usaha Mikro Kecil dan Menengah terkait Hak Kekayaan Intelektual dalam menghadapi masyarakat ekonomi Asean. Dipenogoro Law Jurnal, 3(5).

Benuf, A. (2020). Metodologi Penelitian Hukum sebagai Instrumen Mengurai Permasalahan Hukum Kontemporer. Jurnal Gema Keadilan, 7.

Bethlehn, A. (2018). Upaya Perlindungan Hukum Terhadap Merek Industri UMKM di Indonesia. Jurnal Law and Justice, 4.

Fiedmann, W. (1993). Teori dan Filsafat Hukum. Depok: Raja Grafindo Persada.

Harsono, B. (2014). Tiap Orang Bisa Menjadi Pengusaha Sukses Melalui UMKM. Jakarta: PT Elex Media Komputindo.

Hartini. (2011). Perlindungan Usaha Kecil dan Menengah (UKM) Melalui Hukum Merek. Semarang: Universitas Diponegoro.

Heijber, T. (1988). Filsafat Hukum Dalam Lintasan Sejarah. Yogyakarta: Kanisius.

Hidayah, K. (2017). Hukum Hak Kekayaan Intelektual. Jakarta: Setara Press.

Indayani, L., \& Adelia, W. (2019). Dampak Produk Domestik Bruto dan Inflasi Terhadap Potensi Kebangkrutan UKM di Kota Sidoarjo. Jurnal Manajemen Bisnis, 120 129.

Indrawati, S., \& Setiawan. (2020). Extension of Legal Awareness for the Protection of UMKM Product in Kebumen Regency through Trademark Registration. Jurnal Universitas Muhammaiyah Purworejo, 4 (2).

Laily, N. (2016). Analisis Pengaruh Perkembangan Usaha Kecil Menengah (UKM) Terhadap Pertumbuhan Produk Domestik Regional Bruto (PDRB). Jurnal Pendidikan Ekonomi.

Mamahit, J. (2013). Perlindungan Hukum Atas Merek dalam Perdagangan Barang dan Jasa. Lex Privatum, 90 - 100.

Muhammad, A. (2001). Kajian Hukum Ekonomi Kekayaan IntelektualI. Bandung: Citra Aditya Bakti.

Rajagukguk, E. (2000). Peranan Hukum Di Indonesia: Menjaga Persatuan, Memulihkan 
Ekonomi dan Memperluas Kesejahteraan Sosial. Depok: Universitas Indonesia.

S, L. A. (2017). Perlindungan Hukum Umkm Dari Eksploitasi Ekonomi Dalam Rangka Peningkatan Kesejahteraan Masyarakat. Jurnal Rechts Vinding: Media Pembinaan, $387-402$.

Saputra, M. B., Heniyatun, H., Hakim, H. A., \& Praja, C. B. (2021). The Roles of Local Governments in Accommodating the Registration of SME's Product Trademarks. Amnesti: Jurnal Hukum, 53-59.
Sardjono, A., Prastyo, B. A., \& Larasati, D. G. (2014). Pelaksanaan Perlindungan Hukum Merek untuk Pengusaha UKM Batik di Pekalongan, Solo, dan Yogyakarta. Jurnal Hukum dan Pembangunan, 496 - 517.

Sidarta. (2011). Konsep Diskriminasi Dalam Perspektif Filsafat Hukum, dalam ButirButir Pemikiran Dalam Hukum; Memperingati 70 Tahun Prof. Dr. Arief Sidharta, S.H. 2 ed. Jakarta: Peneribit Refika Aditama. 